\title{
EFFECT OF WPCB POWDER ADDITION AS REDUCTANT ON INDONESIAN NICKELIFEROUS ORE PROCESSING
}

\author{
Reza Miftahul Ulum¹, Dimas Ananda Radhitya ${ }^{1}$, \\ Alfian Ferdiansyah Madsuha ${ }^{1}$, and Faizinal Abidin ${ }^{2}$ \\ ${ }^{1}$ Metallurgical and Materials Engineering Department, UI, Kampus UI Depok, \\ Depok, 16424 \\ ${ }^{2}$ Center for Mineral Resources Development Technology, \\ BPPT-Pusat Teknologi Material, Banten, 15314 \\ E-mail:reza.ulum@ui.ac.id
}

Received: 7 July 2020

Revised: 15 October 2020

Accepted: 22 October 2020

\begin{abstract}
EFFECT OF 5 WT.\% WPCB POWDER AS REDUCTANT ON INDONESIAN LIMONITIC NICKEL ORE PROCESSING. Waste printed circuit boards (WPCB) are among the most valuable parts of electronic waste with one of the fastest-growing waste streams in the world. The purpose of this study is to investigate the possibility of WPCB powder as an alternative reducing agent for the carbothermic process in nickel lateritic ore processing. WPCB waste was mixed with nickel ore at 1100 ÚC in inert atmosphere. In addition, a conventional reductant of coal is also utilized for comparison. Both reductant are varied in concentration of $5 \mathrm{wt} \%$ and $15 \mathrm{wt} \%$. Based on thermogravimetric analysis (TGA) and differential thermogravimetric analysis (DTA) investigation, it is observed that there exists a difference between WPCB powder, nickeliferous ore powder, and the mixture in their decomposed levels. The decomposed gasses of WPCB produced by thermal degradation in the TGA instrument are mainly composed of reduction gas, which plays a critical role in reducing the nickeliferous ore. This study shows that WPCB powder performs comparably to sub-bituminous coal in the pyrometallurgical processing of nickel ore, which is proved by X-Ray Diffraction (XRD) test results that the carbothermic products consists of FeNi, magnetite, wustite and fayalite. It can be concluded than WPCB powder has potential to be utilize as an alternative reductant.
\end{abstract}

Keywords: Electronic waste, WPCB, Nickel ore processing.

\begin{abstract}
ABSTRAK
PENGARUH PEMANFAATAN 5 WT.\% LIMBAH PCB SERBUK SEBAGAI REDUKTAN TERHADAP PENGOLAHAN BIJIH NIKEL INDONESIA. Limbah papan sirkuit (WPCB) adalah salah satu bagian paling berharga dari limbah elektronik dengan salah satu aliran limbah dengan pertumbuhan tercepat di dunia. Tujuan dari penelitian ini adalah untuk mengetahui kemungkinan serbuk WPCB sebagai agen pereduksi alternatif untuk proses karbotermik dalam pengolahan bijih nikel laterit. Limbah WPCB dicampur dengan bijih nikel pada suhu 1100ÚC dalam suasana inert. Selain itu, reduktor batubara konvensional juga digunakan sebagai pembanding. Kedua reduktor divariasikan dengan konsentrasi $5 \mathrm{wt} \%$ dan $15 \mathrm{wt} \%$. Berdasarkan analisis termogravimetri (TGA) dan analisis termogravimetri diferensial (DTA), diamati bahwa terdapat perbedaan antara bubuk WPCB, bubuk bijih nikel, dan campuran dalam tingkat dekomposisi mereka. Gas WPCB yang membusuk yang dihasilkan oleh degradasi termal dalam instrumen TGA terutama terdiri dari gas reduksi, yang memainkan peran penting dalam mengurangi bijih nikel. Studi ini menunjukkan bahwa bubuk WPCB memiliki kinerja yang sebanding dengan batubara sub-bituminus dalam proses pyrometalurgi bijih nikel, yang dibuktikan
\end{abstract}


dengan hasil uji X-Ray Diffraction (XRD) bahwa produk karbotermik terdiri dari FeNi, magnetit, wustit dan fayalit. Dapat disimpulkan bahwa bubuk WPCB berpotensi untuk digunakan sebagai reduktor alternatif.

Kata kunci: Limbah elektronik, WPCB, Pengolahan bijih nikel

\section{INTRODUCTION}

As a common type of e-waste, waste printed circuit boards (WPCB) are increasingly garnering more and more attention as a hot research topic in the resourcing e-waste research field. WPCB is particularly problematic to recycle because of the heterogeneous mix of organic materials, metals, and glass fibers [1]. Nonconventional disposal, dismantling, incineration, shredding, hydrometallurgical and pyrometallurgical methods are widely applied in the e-waste recycling process. The main disadvantages of these methods are their poor economic and environmental effects [2]. The problems arise as a result of an inefficient recycling process. Therefore, an alternative recycling method is needed, which includes process-efficient and environmentally friendly processes. One of the approaches used is the thermochemical treatment of WPCB, through pyrolysis or thermal analysis using thermogravimetric analysis (TGA) in an inert environment [3]. As a new and efficient waste disposal method with low emissions, pyrolysis can recycle all the valuable metals and deal with organic matters in the WPCB [4]. Hence, some research is focusing on using pyrolysis technology to dispose of WPCB [5]. Currently, most research focuses mainly on the pyrolysis product, the pyrolysis kinetics of WPCB, and the control and removal of brominated pollutants [6]. However, recent studies reported that the non-metal fractions in WPCB could be used as a reducing agent to reduce hematite [7] [8].

Previous studies have shown that non-metal fraction products resulting from thermal degradation contain $80-90 \%$ carbon and produce some hydrocarbon gases and char [7]. In addition, the pyrolysis process performed up to a temperature of $1350^{\circ} \mathrm{C}$ indicates that lead levels experience a decrease in concentration up to $72 \mu \mathrm{g} / \mathrm{g}$ due to evaporation. The content of non-metal fractions obtained mostly contains silicon, phosphorus, and copper. Based on the carbon content, the research in this literature is followed by pyrolysis using a nonmetal fraction mixture of WPCB with hematite [7]. The results of the study were then analyzed using X-ray diffraction (XRD). It can be concluded that WPCB utilization as a reducing agent has succeeded in reducing the hematite $[7,8]$.
In this research, we report a new approach based on recent studies mentioned before to use WPCB as a reductant for nickel limonite ore from Indonesia. In order to reduce limonite ore, the carbothermic process is necessary. Some aspects need to be considered, especially in the addition of coal as a reducing agent. This research investigates the reduction capability of the WPCB powder in the process of reducing nickeliferous ores, according to the products produced from thermal characterization and the carbothermic product of nickeliferous ore using WPCB as reductant.

\section{EXPERIMENTAL METHOD}

In this study, a discarded waste printed circuit board (WPCB) from the used computer was selected as the test sample. Firstly, the dismantling process is necessary for the components attached in the discarded WPCB, such as capacitors, battery, integrated circuits, and plastic sockets were removed manually with hot air guns. After dismantling, the WPCB was crushed manually using a grinder into powder until reached the average size of $75 \mu \mathrm{m}$. Afterward, The - WPCB powder was proceeded to magnetic separation.. The non-magnetic WPCB powder was used as reductant in this study.

Sub-bituminous coal and nickeliferrous ore, specifically limonite ore sample were taken from Indonesia and selected as raw materials in this study. The sub-bituminous coal was used as a referencereductant. The prepared limonite ore sample was grinded using a mortar and pestle, and dried. The dried ore was characterized using XRF (X-Ray Fluorescence) analysis as shown in Table 1. All powder samples prepared were classified into non-magnetic WPCB powder, limonite ore powder, and sub-bituminous coal powder. The nonmagnetic WPCB powders were investigated using proximate analysis together with sub-bituminous powder. The proximate analysis results are shown in Table 2. For the thermal analysis result of the sample, a Linsey's thermogravimetric analyzer was utilized. This analysis used two different samples: a mixture of conventional reductant (sub-bituminous coal) and lateritic nickel, and a mixture of WPCB and lateritic nickel. Both coal and WPCB reductant are varied in 
Table 1. Chemical composition of limonite ore

\begin{tabular}{c|c|c|c|c|c|c}
\hline \multicolumn{7}{c}{ Elements } \\
\hline $\mathrm{Fe}$ & $\mathrm{Ni}$ & $\mathrm{Co}$ & $\mathrm{Mg}$ & $\mathrm{Cr}$ & $\mathrm{A} 1$ & $\mathrm{Si}$ \\
\hline $58 \%$ & $0.92 \%$ & $0.05 \%$ & $1.00 \%$ & $2.6 \%$ & $7.4 \%$ & $9.8 \%$ \\
\hline
\end{tabular}

Table 2. Proximate analysis of WPCB and coal

\begin{tabular}{ccccc}
\hline \multirow{2}{*}{ Sample } & \multicolumn{4}{c}{ Proximate analysis (wt\%) } \\
\cline { 2 - 5 } & $\mathrm{M}_{\mathrm{adb}}$ & $\mathrm{A}_{\mathrm{adb}}$ & $\mathrm{V}_{\mathrm{adb}}$ & $\mathrm{FC}_{\mathrm{adb}}$ \\
\hline WPCB & 0.46 & 77.18 & 22.36 & 0.00 \\
Sub-bituminous Coal & 16.96 & 4.22 & 41.50 & 37.32 \\
\hline
\end{tabular}

concentration, $5 \mathrm{wt} . \%$ and $15 \%$ wt.. Heating rates of 10 ${ }^{\circ} \mathrm{C} / \mathrm{min}$ with $10 \pm 0.5 \mathrm{mg}$ for each sample. The starting temperature was set at $50{ }^{\circ} \mathrm{C}$, and $1100{ }^{\circ} \mathrm{C}$ as the final temperature, the result shown in Figure 1.

The non-magnetic WPCB powder and limonite ore powder were thoroughly mixed and weighed $10 \mathrm{mg}$ using mortar and pestle. The $10 \mathrm{~g}$ mixture consists of 95 wt.\% limonite ore powder and 5 wt.\% non-magnetic WPCB powder. Sub-bituminous powder was also used to reduce limonite ore studies for comparison in the result of the reduction. A mixture of sub-bituminous powder and limonite ore was also prepared in the same way. Afterward, the two mixtures were compacted using a hydraulic press machine for 5 minutes, and reduction experiments were performed in a horizontal tubular furnace at $1100{ }^{\circ} \mathrm{C}$ in inert atmosphere. In order to investigate the elemental compound on the crystal structure of sample and product, the dried limonite and the carbothermic products (reduced mixtures) were analyzed using SEM - elemental mapping and XRD techniques.

\section{RESULT AND DISCUSSION}

Table 1 shows the major elements composed the dried ore being used in this study, which consist of low nickel composition and high iron content.

Table 2 shows the proximate analysis data, which consists of the moisture $\left(\mathrm{M}_{\mathrm{adb}}\right)$, ash $\left(\mathrm{A}_{\mathrm{adb}}\right)$ content, volatile $\left(\mathrm{V}_{\mathrm{adb}}\right)$ matter, and fixed carbon $\left(\mathrm{FC}_{\mathrm{adb}}\right)$ in the airdried basis. It indicates that the ash content of WPCB is higher than coal's, while the volatile matter is low compared to coals. It was reported that the high ash content in WPCB could be attributed by ceramic fractions of WPCB substrate, mainly $\mathrm{SiO}_{2}, \mathrm{Al}_{2} \mathrm{O}_{3}$, and $\mathrm{CaO}$ [8]. Furthermore, the volatile content indicates the yield on the carbonization process. Coal yields high volatile matter due to the larger carbon presence compared to WPCB.

According to the literature, it was reported that WPCB powder TGA curve was showing the mass's loss for approximately $75 \%$ of the initial mass. Figure 1(a) shows the TGA and DSC curves of four samples. The maximum weight loss rate recorded in the curve is a loss of $30,4 \% / \mathrm{min}$, where this occurs at the range of $260-$ $340{ }^{\circ} \mathrm{C}$. Further decomposition after the temperature range of high mass loss was relatively flat, which means the WPCB powder slowly decomposed up to the end of heating. After heating was completed, the final weight of decomposed WPCB powder was about $60 \%$ of the initial mass due to the volatile compounds that fully decomposed.

It can also be seen from the TGA curve of WPCB powder that there was no decomposition observed until $250{ }^{\circ} \mathrm{C}$ due to moisture content. Meanwhile, the TGA curve of limonite ore shows a different pattern compared

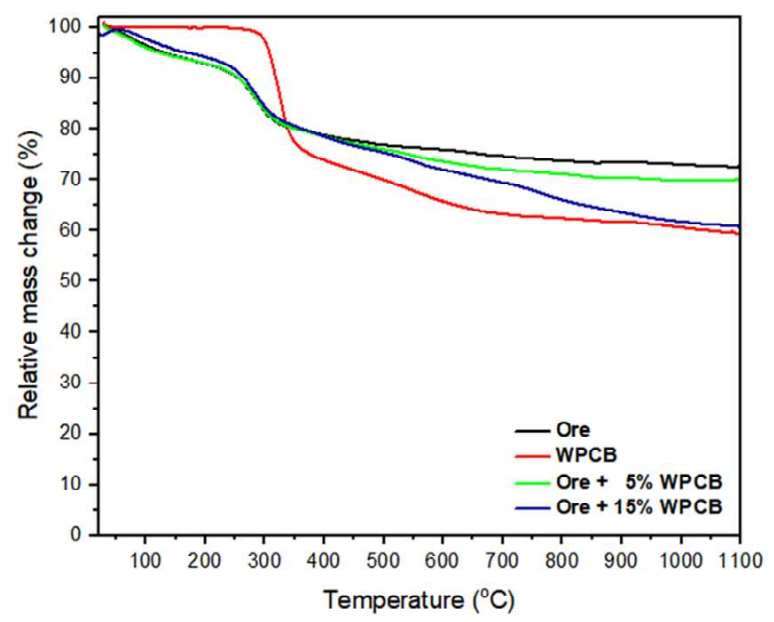

(a)

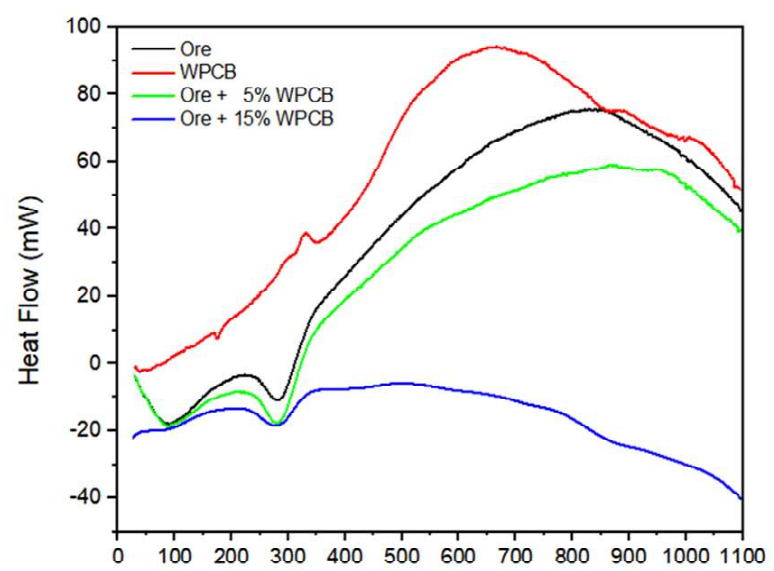

Figure 1. TGA curves (a) and DSC curves (b) for three samples with a heating rate of $10{ }^{\circ} \mathrm{C} / \mathrm{min}$. 

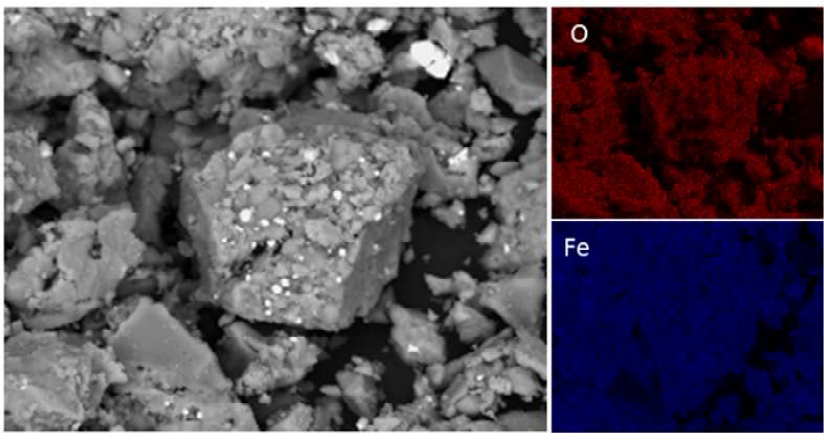

(a)
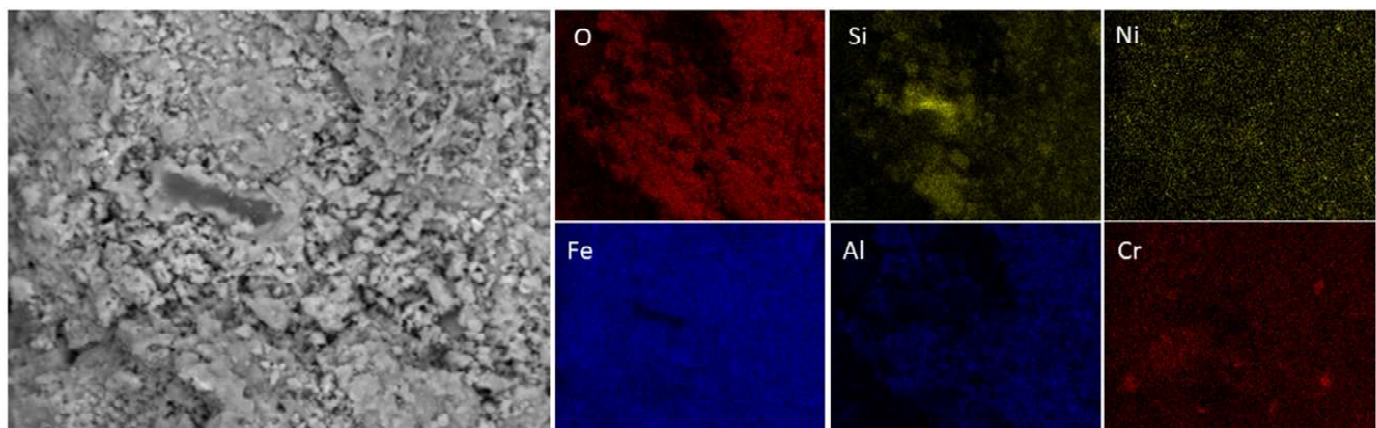

(b)

Figure 2. Elemental mapping from SEM image of (a) Limonite +5 wt. $\%$ WPCB; (b) Limonite +5 wt. $\%$ Sub-bituminous
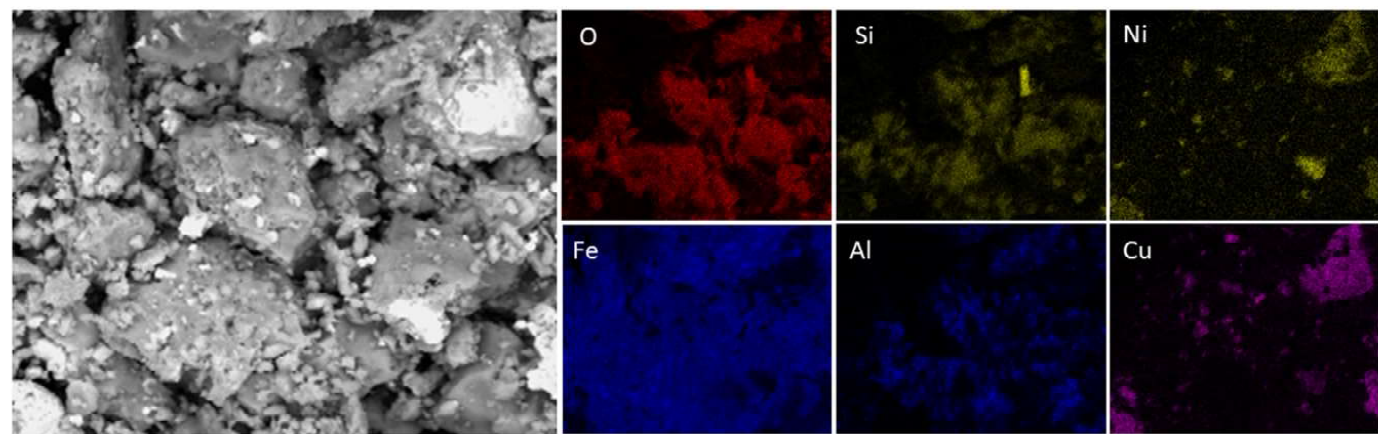

(a)
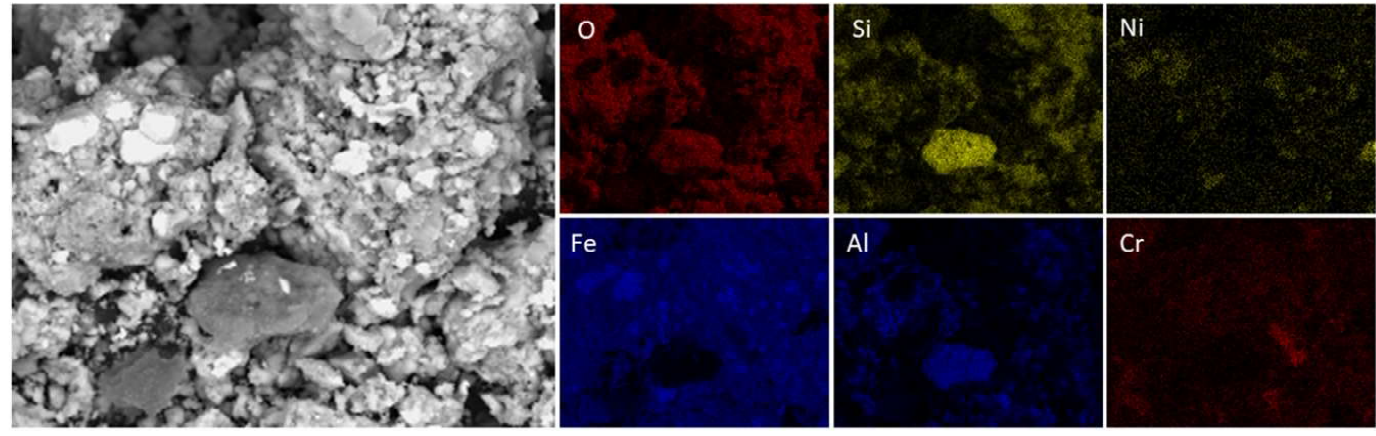

(b)

Figure 3. Elemental mapping from SEM image of (a) Limonite +15 wt.\% WPCB; (b) Limonite +15 wt. $\%$ Sub-bituminous

to the WPCB curve. Recent research reported to conduct the TG analysis on Indonesian limonite ore showed a similar curve pattern with the current research [9]. The TGA curve of the mixing samples of WPCB powder and limonite ore was also recorded in Figure 1. It can be seen from the curve that with the addition of $5 \%$ of WPCB powder into limonite, a different trend compared to the limonite ore curve is obtained. Significant mass loss of the mixture occurred in the same range as limonite ore, but a more substantial weight loss of $-23 \% /$ min was 


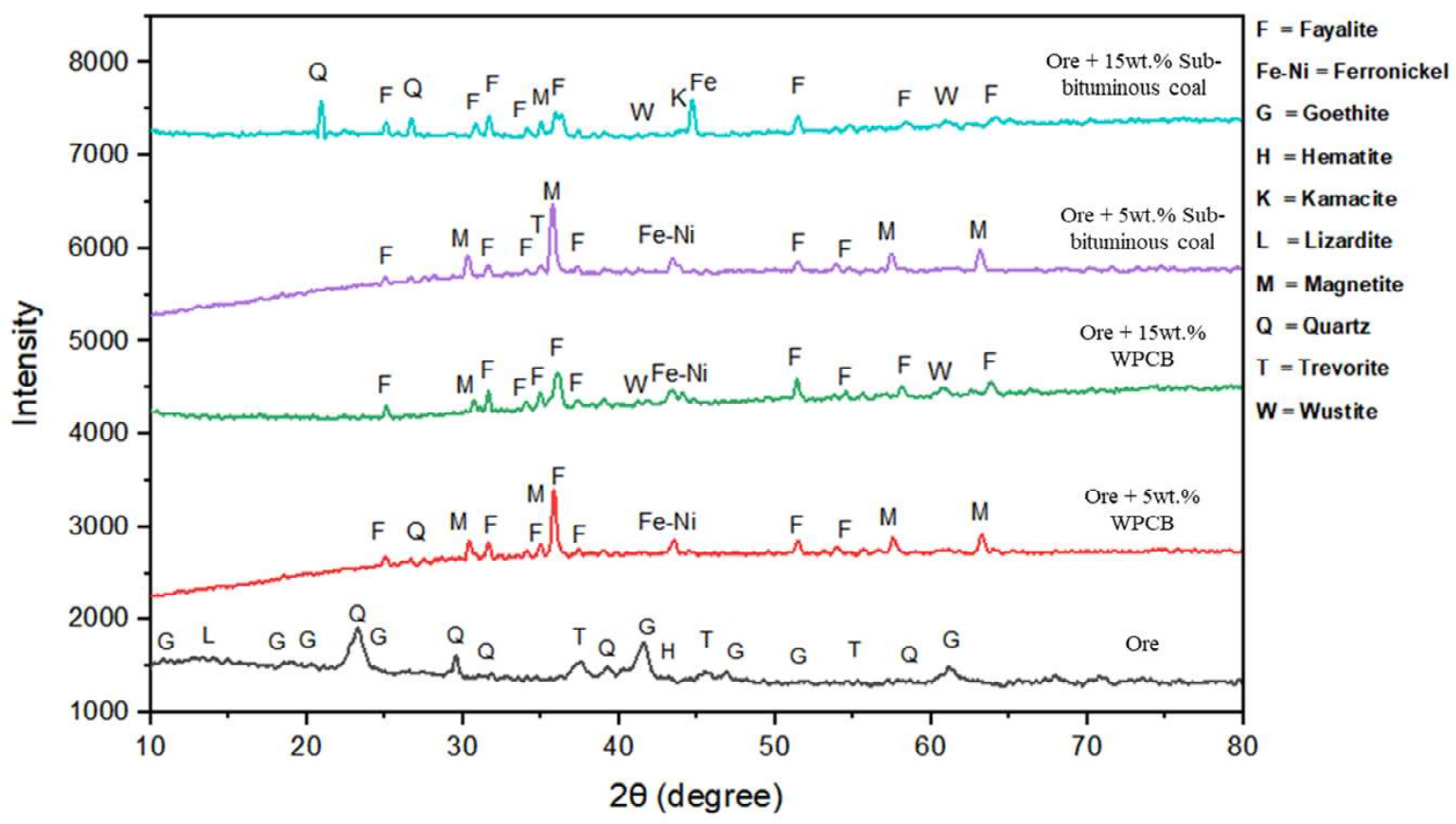

Figure 4. XRD pattern of dried limonite ore, carbothermic product of limonite ore $+5 \mathrm{wt} . \% \mathrm{WPCB}$ powder, limonite ore +15 wt. $\%$ WPCB powder, limonite ore +5 wt. $\%$ sub-bituminous powder and limonite ore +15 wt. $\%$ sub-bituminous powder.

recorded. However, further heating before the range shows a larger maximum mass loss rate of $-5,8 \% / \mathrm{min}$ at $440-740{ }^{\circ} \mathrm{C}$, signified with a gradual curve. At the end of heating, it is demonstrated that the addition of $5 \%$ of WPCB powder into limonite ore is successful in decreasing the final residue of the mixture by $\sim 71 \%$.

From the DSC curves, according to table 1, WPCB powder has a relatively large number of volatile compounds. It is assumed that these compounds are from organic materials such as epoxy resin, plastics, flame retardants, and fillers, which are mainly added in PCB fabrication. During this stage, these volatile compounds were devolatilized, resulting in a significant mass loss of $-25 \%$ of the sample. In Figure $1(\mathrm{~b})$, two exothermic peaks at $325-340{ }^{\circ} \mathrm{C}$ and $523-860{ }^{\circ} \mathrm{C}$ indicate the decomposition of the organic materials mentioned before, released in gaseous forms.

Recent research shows that the gas that escapes from the WPCB during heating is $\mathrm{CO}, \mathrm{CO}_{2}, \mathrm{HBr}$, and hydrocarbons [1]. The addition of $15 \%$ WPCB also experiences the highest mass removal in the temperature range $200-300{ }^{\circ} \mathrm{C}$. What distinguishes it from the addition of 5\% WPCB is the final mass, where the mixture that has the highest total percentage of final mass is $5 \%$ WPCB addition (70\% initial mass) and the lowest was $15 \%$ WPCB (61\% initial mass). The endothermic curve shows the same trend, namely in the temperature range of $50-150{ }^{\circ} \mathrm{C}$ and $245-330^{\circ} \mathrm{C}$.
It is also shown that in the range of $523-860^{\circ} \mathrm{C}$, $\mathrm{H}_{2}$ was released in large amounts due to the breakage of hydrocarbon chains. The DSC curve shows two endothermic peaks at $90^{\circ} \mathrm{C}$ and $290^{\circ} \mathrm{C}$ and an exothermic peak at $840{ }^{\circ} \mathrm{C}$ for the limonite ore powder. Moisture evaporation occurred at $90^{\circ} \mathrm{C}$, which is contributed by trapped water. Moreover, goethite's dehydroxylation to form hematite occurred at $290{ }^{\circ} \mathrm{C}$ [9]. The exothermic peak at $840{ }^{\circ} \mathrm{C}$ indicates the increasing amount of the hematite phase and lizardite decomposition into the forsterite phase [9].

The mixing sample's DSC curve shows how the addition of WPCB powder as a reductant shifts the exothermic peak to a higher temperature. Two endothermic peaks observed have the same tendencies as limonite ore. However, the exothermic peak at $760-$ $1020{ }^{\circ} \mathrm{C}$ clearly shows that the reduction process took place. The transformation of goethite and $\mathrm{Fe}_{2} \mathrm{O}_{3}$ obtains phase formation of magnetite $\left(\mathrm{Fe}_{3} \mathrm{O}_{4}\right)$. Further heating up to $1100{ }^{\circ} \mathrm{C}$ will allow the hematite phase's reaction, including the formation of $\mathrm{H}_{2}$ gas [8]. It accelerates the formation of magnetite $\left(\mathrm{Fe}_{3} \mathrm{O}_{4}\right)$ and fayalite $\left(\mathrm{Fe}_{2} \mathrm{SiO}_{4}\right)$ while the hematite phase decreases [10].

As shown in Figure 2 (a), the SEM image from carbothermic product of limonite $-5 \mathrm{wt} . \% \mathrm{WPCB}$; the mixture mainly consists of iron compound-covering all the surfaces of the product, followed by oxygen, aluminum, and silicon. On this Figure can also be seen 
that some areas was clustered by elemental $\mathrm{Ni}$ and $\mathrm{Fe}$ which is indicated that the carbothermic product with 5 wt.\% WPCB addition was successfully reduced the nickel ore and produced FeNi which has been confirmed by XRD analysis in the Figure 4. It is also can be seen that the metallic copper from WPCB powder remained as metal after the reduction process is conducted which is shown by the Figure 2 (a) and 3 (a), the $\mathrm{Cu}$ particles is not associated with other element. Whereas nickel and chromium were detected clustering in some areas in the oxide-compound form. According to Figure. 2 (b), with sub-bituminous coal as a reductant, it may be attributed to the formation of more magnetite $\left(\mathrm{Fe}_{3} \mathrm{O}_{4}\right)$ in comparison to the addition WPCB powder due to the high reduction temperature [11]. Moreover, $\mathrm{Si}$ and $\mathrm{Al}$ were also detected with a low distribution, leading to form $\mathrm{SiO}_{2}$ and $\mathrm{Al}_{2} \mathrm{O}_{3}$ phases, which is confirmed by the XRD result shown in the Figure 4. The more WPCB addition showed the larger FeNi particles which can be seen in the Figure. 3 (a) and confirmed by the XRD analysis results, but the metallic copper being produced by this parameter was also larger than the carbothermic product of the addition of $5 \mathrm{wt} . \%$ WPCB.

Based on the XRD result of dried limonite and processed with crystallographic software (Highscore), some phases were detected, such as goethite, quartz, kaolin, lizardite, hematite, and trevorite. On the other hand, the graph clearly shows the appearances of FeNi, magnetite and fayalite peaks, which appear dominant on the carbothermic products both with WPCB powder and sub-bituminous addition. Simultaneously, the hematite phase was not dominant, indicating the occurrence of the reduction process. This magnetite and fayalite peaks were observed in each of the products. According to the XRD result, the reduction process using WPCB powder confirms that WPCB powder can be used as an alternative reductant since the reduction ability of WPCB powder is like sub-bituminous coal powder.

In this study, the utilization of WPCB powder shows its tendency to be used as a reductant. However, the metallic copper product or other $\mathrm{Cu}$ compound resulted after the carbothermic process was done has to be separated. The result shows that 5wt.\% WPCB powder performs comparably to $5 \mathrm{wt} . \%$ sub-bituminous coal addition as a reductant in the pyrometallurgical processing of nickeliferous ore. The more concentration of WPCB powder addition will promote the formation of $\mathrm{CuFe}_{2} \mathrm{O}_{4}$ or other copper-compound or copper metallic products [12] after the reduction process was done, which is an unfavorable carbothermic product in nickel ore processing. The further separation process is required to reduce this metallic product.

\section{CONCLUSION}

In this study, the use of waste printed circuit board (WPCB) powder is successful to be utilized as an alternative reductant for the lateritic nickel ore reduction process. Based on result and characterization, the $5 \mathrm{wt} \%$ of WPCB shows promising recipe to be used as reductant. It shows the lower metallic copper product and produced the comparably results to the $15 \mathrm{wt} \%$ of WPCB. The finding is significant in order to find the optimum concentration of WPCB as a reductant.

\section{REFERENCES}

[1] F. Diaz and F. Diaz. "Comparative Analysis About Degradation Mechanisms of Printed Circuit Boards (PCBs) in Slow and Fast Pyrolysis: The Influence of Heating Speed." Journal of Sustainable Metallurgy, vol. 7, 2018.

[2] M. Kaya. "Current WEEE Recycling Solutions," in Woodhead Publishing Series in Electronic and Optical Materials, 2018.

[3] P. Evangelopoulos, "Pyrolysis of Waste Electrical and Electric Equipment (WEEE) for Energy Production and Material Recovery." M.Sc. thesis, KTH Royal Institute of Technology, Sweden, 2014.

[4] R. Font. Decomposition of Organic Wastes: Thermal Analysis and Evolution of Volatiles, 2nd ed., vol. 6. Elsevier B.V., 2018.

[5] J. Hao, H. Wang, S. Chen, B. Cai, L. Ge, and W. Xia. "Pyrolysis characteristics of the mixture of printed circuit board scraps and coal powder." Journal of Waste Management, vol.34, No.10, pp. 1763-1769, Oct. 2014.

[6] B. Ghosh, M. K. Ghosh, P. Parhi, P. S. Mukherjee, and B. K. Mishra. "Waste Printed Circuit Boards recycling: an extensive assessment of current status." Journal of Cleaner Production Volume, vol. 94, pp. 5-19, May 2015.

[7] R. Rajarao, V. Sahajwalla, R. Cayumil, M. Park, and R. Khanna. "Novel Approach for Processing Hazardous Electronic Waste." Procedia Environmental Sciences, vol. 21, pp. 33-41, 2014.

[8] D. Attah-kyei. "Investigating the Use of Printed Circuit Board Leach Residue as Reductant in Pyrometallurgical operations." M.Eng Thesis, Stellenbosch University, UK, Apr. 2019. 
[9] H.T.B.M. Petrus, A.D.P. Putera, E. Sugiarto, I. Perdana, IW. Warmada, F. Nurjaman, W. Astuti, A. T. Mursito. "Kinetics on roasting reduction of limonitic laterite ore using coconut- charcoal and anthracite reductants." Minerals Engineering, vol. 132, no. 2, pp. 126-133, 2019.

[10] W. Mayangsari, and A. B. Prasetyo. "Phase Transformation of Limonite Nickel Ores with $\mathrm{Na}_{2} \mathrm{SO}_{4}$ Addition in Selective Reduction Process." in IOP Conf. Ser. Mater. Sci. Eng., 2017, vol. 202, no.1.
[11] E. Febriana, A. Manaf, A. B. Prasetyo, and W. Mayangsari. "Thermal characteristic of limonite ore upon calcination and reduction." In AIP Conf. Proc., 2018, vol. 1964, no. 1, p. 20026.

[12] R. M. Ulum, A. K. Wicaksana and F. Abidin. "Effect of Temperature in Carbothermic Reduction of Indonesian Limonite Ore Using Printed Circuit Boards as Reducing Agent." Materials Science Forum, vol. 1009, pp. 155-161, Aug. 2020. 